\title{
Impact of ICDS services in urban and rural area beneficiaries children of Ghaziabad, Uttar Pradesh, India: a comparative evaluation study
}

\author{
Narendra Singh $^{1} *$, Pankaj Gupta ${ }^{2}$
}

\author{
${ }^{1}$ Department of Community Medicine Santosh Medical College, Ghaziabad, UP, India \\ ${ }^{2}$ Department of Community Medicine, Rama Medical College, NH-24, Ghaziabad, UP, India
}

Received: 09 November 2015

Revised: 14 December 2015

Accepted: 15 December 2015

\author{
*Correspondence: \\ Dr. Narendra Singh, \\ E-mail: narendra74singh@yahoo.in
}

Copyright: () the author(s), publisher and licensee Medip Academy. This is an open-access article distributed under the terms of the Creative Commons Attribution Non-Commercial License, which permits unrestricted non-commercial use, distribution, and reproduction in any medium, provided the original work is properly cited.

\begin{abstract}
Background: The rich experience of ICDS has brought about a welcome transition from welfare orientation to a new challenging perspective of social change. It aims at enhancing survival and development of children from the vulnerable sections of the society. Being the world's largest outreach program targeting infants and children below 6 years of age, expectant and nursing mothers.

Methods: A longitudinal and comperative study of morbidity (Prevalence and Incidence) among children bellow 6 years of age was conducted in two adjoining areas ,conducted in adjoining area of Rural health training centre and urban health training centre of both area ,covered by ICDS Centre of a concern medical college of Ghaziabad Uttar Pradesh.Impact was assessed ( nutritional status and incidence of illness) in children of both the area.

Results: The overall incidence of morbidity was significantly higher in rural ICDS covered area (7.97episode per child per year) than in urban ICDS area (5.43 episodes per child per year) .

On initial survey, overall prevalence of morbidity was significantly higher in rural ICDS area(54.14\%) than urban area ICDS.(45.85\%).

Conclusions: There are program gaps in coverage of supplementary nutrition in rural ICDS area children, its regular supply to the beneficiaries, in pre-school activities coverage, recording of immunization, and regular health check-up of beneficiaries and referral of sick children.
\end{abstract}

Keywords: ICDS impact, Rural and urban, Ghaziabad, Uttarpradesh

\section{INTRODUCTION}

ICDS is the world's largest program for the holistic development of children aged 0-6 years, expectant and lactating mothers and selected adolescent girls. With a view to improving the health and nutritional status of children in the age group of 0-6 years, pregnant women and lactating mothers, the Special Nutrition Program has been included as one of the most important components of the ICDS Program. It also aims at improving awareness of the community as a whole, and brings about behavior change. ICDS has provided significant assistance to as the nation's health and education system for decades. ${ }^{1}$ The Ministry of Women and Child Development (MWCD) of India established ICDS in 1975. ${ }^{2}$ It is the world's largest early child development program. The objective of this programme to improve the nutritional status of pre-school children in addition to other services.

Malnutrition is "the syndrome that results from the interaction between poor diets and disease and leads to most of the anthropometric deficits observed among children in the worlds less developed countries" (WHO 1995). ${ }^{3}$ 
Government of India with partnership of the international agencies like UNICEF (United nation children fund), CARE (Cooperative for assistance and relief everywhere) and WFP (World food programme) provides a package of services to children below six years of age, adolescent girls, expectant and nursing mothers through the network of Anganwadi ${ }^{4}$ The rich experience of ICDS has brought about a welcome transition from welfare orientation to a new challenging perspective of social change. It aims at enhancing survival and development of children from the vulnerable sections of the society. ICDS has generated interest worldwide among academicians, planners, policy makers, administrators and those responsible for implementation. According to National Family Health Survey-3, though $81.1 \%$ children under age six years were covered by AWCs, children who received any service from AWC were only 28.4\%.5.$^{5}$ Systematic evaluations of development interventions often lead to the evolution of sharper policies based on hardcore evidence. It is standard practice to look into the relevance, effectiveness, efficiency, impact and sustainability of the intervention in question. ${ }^{6}$ This study was designed to evaluate if the services provided by the scheme are utilized adequately and effectively by the community or not. Such studies will make the authorities aware of the factual situation regarding the scheme.

Aims and objectives of the study were,

1 To compare the morbidity in children bellow 6 years of age in a rural and urban ICDS centre.

2 To assess nutritional status of the same children in both the area.

\section{METHODS}

A longitudinal and comparative study of morbidity (Prevalence and Incidence) among children bellow 6 years of age was conducted in two adjoining areas ,both area covered by ICDS Centre. In this study ICDS centre covered are adjoining area of rural health training centre and urban health training centre, of a concern medical college Ghaziabad, Uttar Pradesh. The total population of urban area is 28351 and of rural area it is 10245. The study started in July 2014 and continued till March 2015.The study divided in to two phases, one month for socio-demographic survey and 6month for follow up for morbidity. A predesigned pretested proforma was used to collect the information about the children. The areas are predominantly inhabited by Hindu community. Most of people are working as daily wedge earner like laborers, factory workers, vendors, Masson etc. There are total 26 Anganwadi centers in urban area and 11 Anganwadi centre in rural area. Out of the total Anganwadi in both area, 10 Anganwadi was selected from rural area and 10 from urban area by random sampling and all of the children bellow 6 years of age in the selected Anganwadi constituted the study group. The 186 children were enrolled in rural selected Anganwadi centre where as 181 in urban selected Anganwadi centre. The houses of all children in the selected groups were visited and best effort was made to include every child. It was possible to include 181 children from this area. Rest of the children could not include in the study eighter due to nonavailability or persistent noncooperation on the part of parents, despite repeated visits. Survey was carried out for estimating the prevalence of illness, Immunization status, Nutritional status feeding practices. Information was also collected on housing conditions, socio-economic status literacy status and occupational status of parents, type and size of family, living order. The informant was always mothering. In case of non availability of mother father was the informant.

The age of children was determined on the basis of date of birth or according to the local calendar in case of date of birth was not known. For prevalence of morbidity, diagnosis was made on the basis of history of present and past illness and clinical examination of every child. In case of doubt about diagnosis, child was referred to the pediatrician not less than the level of senior resident. Kuppu-swamy classification was used to calculate socioeconomic status of children's family.

Anthropometric examination was done to assess nutritional status. Recumbent lengths in case of children bellow 2 years of age and standing length for children above 2 years. Every fortnightly information about morbidity of all the children included in the study was obtained by home visit. Morbidity during follow-up period was analyzed on the basis of children months. Total follow-up period (no. of children $X$ period of study) in the ICDS (Urban) 1086 months and ICDS (Rural) 1116 children months. However 27 children -months in urban ICDS 25 children months in non ICDS area were lost to follow-up because of drop outs. Therefore information were available only for 1059 children months (97.51\%) and 1091 children months (97.75\%) in ICDS Urban and Rural ICDS respectively. Z test were applied to obtain $\mathrm{p}$ value for compression. Result were tabulated and analyzed by SPSS softwere- 20 .

\section{RESULTS}

Table 1: Distribution of children according to age and sex in rural and urban ICDS.

\begin{tabular}{|lllll|}
\hline \multirow{2}{*}{ Age(Months) } & \multicolumn{2}{l|}{ ICDS (Urban) } & \multicolumn{2}{l|}{ ICDS (Rural) } \\
\cline { 2 - 5 } & $\mathbf{N}^{*}$ & $\mathbf{\%}$ & $\mathbf{N}$ & $\boldsymbol{\%}$ \\
\hline$<6$ & 12 & 6.63 & 13 & 6.99 \\
\hline$>6-12$ & 24 & 13.26 & 25 & 13.44 \\
\hline$>12-36$ & 75 & 41.44 & 77 & 41.40 \\
\hline$>36-72$ & 70 & 38.67 & 71 & 38.17 \\
\hline Total (0-72) & 181 & 100 & 186 & 100 \\
\hline
\end{tabular}

$\mathrm{N}^{*}=$ Total Number of participants

Total 181 children were selected from Urban ICDS centre and 186 from rural ICDS centre (Table-1).Children belonged to only two religions, Hindu and Muslim in 
both the study area. Majority of children belong to Hindu family in both the area. Majority of children in both the groups $(59.12 \%$ in urban area and $61.83 \%$ in rural area) belongs to class IV and $29.83 \%$ of children of urban and $26.34 \%$ of rural belongs to class III.

Table 2: Distribution of children according to different characteristics.

\begin{tabular}{|c|c|c|c|c|}
\hline \multirow[t]{2}{*}{ Characteristics } & \multicolumn{2}{|c|}{$\begin{array}{l}\text { ICDS } \\
\text { (Urban) }\end{array}$} & \multicolumn{2}{|c|}{ ICDS (Rural) } \\
\hline & $\mathrm{N}$ & $\%$ & $\mathrm{~N}$ & $\%$ \\
\hline Total & 181 & 100 & 186 & 100 \\
\hline \multicolumn{5}{|l|}{ Religions } \\
\hline Hindu & 175 & 96.68 & 177 & 95.16 \\
\hline Muslim & 6 & 3.32 & 9 & 4.84 \\
\hline \multicolumn{5}{|c|}{ Socio economic status } \\
\hline Upper(Class I) & 0 & 0 & 0 & 0 \\
\hline $\begin{array}{l}\text { Upper } \\
\text { middle(Class II) }\end{array}$ & 17 & 9.3 & 21 & 10.75 \\
\hline $\begin{array}{l}\text { Lower middle } \\
\text { (Class III) }\end{array}$ & 54 & 29.83 & 48 & 26.34 \\
\hline $\begin{array}{l}\text { Upper } \\
\text { lower(Class IV) }\end{array}$ & 107 & 59.12 & 115 & 61.83 \\
\hline Lower(Class V) & 3 & 1.66 & 2 & 1.07 \\
\hline \multicolumn{5}{|c|}{ Immunization status } \\
\hline No Immunization & 0 & 0 & 1 & 0.68 \\
\hline $\begin{array}{l}\text { Partial } \\
\text { Immunization }\end{array}$ & 51 & 28.18 & 57 & 30.65 \\
\hline $\begin{array}{l}\text { Complete } \\
\text { Immunization }\end{array}$ & 130 & 71.82 & 128 & 68.82 \\
\hline \multicolumn{5}{|c|}{ Nutritional status 36700} \\
\hline Normal & 113 & 62.43 & 76 & 40.86 \\
\hline Grade I & 41 & 22.65 & 57 & 30.64 \\
\hline Grade II & 15 & 7.73 & 38 & 20.43 \\
\hline Grade III & 11 & 6.07 & 7 & 3.76 \\
\hline Grade IV & 1 & 0.55 & 8 & 4.30 \\
\hline
\end{tabular}

There was higher percentage $(71.82 \%)$ of coverage of completely immunization in urban ICDS area as compare to rural ICDS $(68.82 \%)$ Over all prevalence of protein energy malnutrition was higher in rural ICDS (59.14\%) than urban ICDS (37.57\%) (Table-2).

In the ICDS area, $83.42 \%$ of children suffered from at least one spell of sickness during the 6 month of follow up, while in rural ICDS area the percentage of similar children was $95.69 \%$. The difference was statically significant (Table-3).

All types of morbidities (except others) show higher affinity for affinity for urban ICDS group of children. The difference between two areas was statically significant in respect of all types of morbidities excluding pyrexia, chicken pox and injuries (Table-3).

The most common morbidity in both the area was respiratory (Urban ICDS area-57.51\%, rural-71.51\%). It was followed by Gastro intestinal diseases (41.98\%) Pyrexia $(24.31 \%)$ skin diseases $(14.19 \%)$ and eye diseases $14.36 \%$ on the other hand in rural ICDS area Gastro intestinal diseases $(70.43 \%)$ skin diseases $(37.09 \%)$ and eye diseases $33.33 \%$ Pyrexia $(27.42 \%)$.This compression shows the rural ICDS centers still to upgrade (Table-3).

Table 3: Distribution of children according to morbidity pattern.

\begin{tabular}{|c|c|c|c|c|c|c|}
\hline \multirow[b]{2}{*}{$\begin{array}{l}\text { Morbid } \\
\text { ity }\end{array}$} & \multicolumn{2}{|c|}{ Urban ICDS } & \multicolumn{2}{|c|}{ Rural ICDS } & \multirow[b]{2}{*}{$\mathbf{Z}$} & \multirow{2}{*}{$\begin{array}{l}P \\
\text { value }\end{array}$} \\
\hline & $\begin{array}{l}\text { No. of } \\
\text { children }\end{array}$ & n & $\begin{array}{l}\text { No. of } \\
\text { children }\end{array}$ & $\%$ & & \\
\hline $\begin{array}{l}\text { Respirat } \\
\text { ory }\end{array}$ & 104 & 57.45 & 133 & 71.51 & 2.84 & $<0.01$ \\
\hline GIT & 76 & 41.98 & 131 & 70.43 & 5.73 & $<0.01$ \\
\hline Skin & 27 & 14.91 & 69 & 37.09 & 5.01 & $<0.01$ \\
\hline Eye & 26 & 14.36 & 62 & 33.33 & 4.39 & $<0.01$ \\
\hline Pyrexia & 44 & 24.31 & 51 & 27.42 & .68 & $>0.05$ \\
\hline Measles & 21 & 11.6 & 48 & 25.81 & 3.56 & $<0.01$ \\
\hline Ear & 12 & 6.63 & 21 & 11.29 & 3.49 & $<0.01$ \\
\hline Injuries & 16 & 8.84 & 19 & 10.21 & 0.45 & $>0.05$ \\
\hline $\begin{array}{l}\text { Chicken } \\
\text { pox }\end{array}$ & 5 & 2.76 & 8 & 4.30 & 1.92 & $>0.05$ \\
\hline Others & 7 & 3.8 & 2 & 1.08 & 1.68 & $>0.05$ \\
\hline Total & 151 & 83.42 & 178 & 95.69 & 3.92 & $<0.01$ \\
\hline
\end{tabular}

*Children who suffered from at least one spell of sickness during the period of study.

Average duration of sickness /Child /Year in Urban ICDS area was 40.15 while in rural ICDS it was 54.68 means 24 days of illness in a year in urban area and 27.34 days of illness in rural ICDS area children that is burden of morbidity in rural area is very high (Table-4).

Among the leading causes of morbidity average duration of sickness because of respiratory diseases, GIT diseases, eye diseases and pyrexia was higher in rural ICDS area although the difference was not statically significant. In contrary to the foregoing observations, the average duration of sickness caused by skin and ear diseases was significantly higher in Urban ICDS area (Table-4).

\section{DISCUSSION}

In the present study total 367 children were enrolled. Out of these 181 were from urban ICDS area and 186 were from rural ICDS area. In present study complete immunization was more in urban ICDS area (71.82) than rural area $(68.82 \%)$. It may be due to more awareness of mothers in urban area. It was also seen that educational status of mothers and socioeconomic status in urban area was better than rural area but it is better than percentage of full immunization coverage survey done by DLHS-3 (District level household and family survey) in Ghaziabad district, where full immunization coverage of rural area (29.3,) and urban area (35.2) of Ghaziabad while according to NFHS -3 full immunization coverage of rural area (20.5,) and urban area (33.0) $)^{8,9}$ One unimmunized child found in the rural ICDS study area. 
Table 4: Duration of sickness and morbidity pattern.

\begin{tabular}{|c|c|c|c|c|c|c|c|c|c|c|}
\hline \multicolumn{5}{|c|}{ Urban ICDS } & \multicolumn{4}{|c|}{ Rural ICDS } & \multirow[b]{2}{*}{$\begin{array}{l}\mathbf{Z} \\
\text { value }\end{array}$} & \multirow[b]{2}{*}{$\begin{array}{l}\mathbf{P} \\
\text { value }\end{array}$} \\
\hline Diseases & $\begin{array}{l}\text { Childr } \\
\text { en } \\
\text { months }\end{array}$ & $\begin{array}{l}\text { Sickn } \\
\text { ess } \\
\text { days }\end{array}$ & $\begin{array}{l}\text { Average } \\
\text { duration } \\
\text { of } \\
\text { sickness } \\
\text { /child/ } \\
\text { month }\end{array}$ & $\begin{array}{l}\text { Average } \\
\text { duration } \\
\text { of } \\
\text { sickness } \\
\text { /child } \\
\text { /year }\end{array}$ & $\begin{array}{l}\text { Children } \\
\text { months }\end{array}$ & $\begin{array}{l}\text { Sickn } \\
\text { ess } \\
\text { days }\end{array}$ & $\begin{array}{l}\text { Average } \\
\text { duration } \\
\text { of } \\
\text { sickness } \\
\text { /child/ } \\
\text { month }\end{array}$ & $\begin{array}{l}\text { Duratio } \\
\text { n of } \\
\text { sickness } \\
\text { /child } \\
\text { /year }\end{array}$ & & \\
\hline $\begin{array}{l}\text { Respirato } \\
\text { ry }\end{array}$ & $\begin{array}{l}608 \\
(104)\end{array}$ & 1003 & $\begin{array}{l}1.65+ \\
-1.00\end{array}$ & 19.79 & $\begin{array}{l}778 \\
(133)\end{array}$ & 1350 & $\begin{array}{l}1.74+ \\
-0.83\end{array}$ & 20.82 & $\mathrm{Z}=0.75$ & $\mathrm{p}>0.0$ \\
\hline GIT & $\begin{array}{l}447 \\
(76)\end{array}$ & 744 & $\begin{array}{l}1.66+ \\
-1.01\end{array}$ & 19.97 & $\begin{array}{l}765 \\
(131)\end{array}$ & 1279 & $\begin{array}{l}1.67+ \\
-0.72\end{array}$ & 20.06 & $\mathrm{Z}=0.5$ & $\mathrm{p}>0.0$ \\
\hline Skin & $\begin{array}{l}159 \\
(27)\end{array}$ & 308 & $\begin{array}{l}1.94+ \\
-1.13\end{array}$ & 23.25 & $\begin{array}{l}407 \\
(69)\end{array}$ & 618 & $\begin{array}{l}1.52+ \\
-0.67\end{array}$ & 18.22 & $\mathrm{Z}=2.21$ & $\mathrm{P}=<0.0$ \\
\hline Eye & $\begin{array}{l}153 \\
(26)\end{array}$ & 164 & $\begin{array}{l}1.07+ \\
-0.31\end{array}$ & 12.86 & $\begin{array}{l}367 \\
(62)\end{array}$ & 407 & $\begin{array}{l}1.11+ \\
-0.45\end{array}$ & 13.30 & $\mathrm{Z}=0.4$ & $p>0.0$ \\
\hline Pyrexia & $\begin{array}{l}251 \\
(44)\end{array}$ & 245 & $\begin{array}{l}0.94+ \\
-0.41\end{array}$ & 11.71 & $\begin{array}{l}295 \\
(51)\end{array}$ & 333 & $\begin{array}{l}1.13+ \\
-0.55\end{array}$ & 13.55 & $\mathrm{Z}=1.9$ & $\mathrm{p}>0.0$ \\
\hline Measles & $\begin{array}{l}126 \\
(21)\end{array}$ & 193 & $\begin{array}{l}1.53+ \\
-0.23\end{array}$ & 18.38 & $\begin{array}{l}282 \\
(48)\end{array}$ & 459 & $\begin{array}{l}1.63+ \\
-0.32\end{array}$ & 19.53 & $\mathrm{Z}=1.25$ & $\mathrm{p}>0.0$ \\
\hline Ear & $\begin{array}{l}70 \\
(12)\end{array}$ & 148 & $\begin{array}{l}2.1+ \\
-0.69\end{array}$ & 25.37 & $\begin{array}{l}125 \\
(21)\end{array}$ & 135 & $\begin{array}{l}1.08+ \\
-0.15\end{array}$ & 12.96 & $Z=3.4$ & $\mathrm{P}=<0.0$ \\
\hline Injuries & $\begin{array}{l}92 \\
(16)\end{array}$ & 110 & $\begin{array}{l}1.19+ \\
-0.58\end{array}$ & 14.34 & $\begin{array}{l}113 \\
(19) \\
\end{array}$ & 95 & $\begin{array}{l}0.84+ \\
-0.19\end{array}$ & 10.08 & $Z=2.5$ & $\mathrm{P}=<0.0$ \\
\hline $\begin{array}{l}\text { Chicken } \\
\text { pox }\end{array}$ & $30(5)$ & 47 & $\begin{array}{l}1.57+ \\
-0.15\end{array}$ & 18.8 & $\begin{array}{l}48 \\
(8) \\
\end{array}$ & 72 & $\begin{array}{l}1.50+ \\
-0.21\end{array}$ & 18.00 & $\mathrm{Z}=1.17$ & $\mathrm{p}>0.0$ \\
\hline Others & $42(7)$ & 56 & $\begin{array}{l}1.33+ \\
-0.73\end{array}$ & 16.0 & $\begin{array}{l}12 \\
(2)\end{array}$ & 10 & $\begin{array}{l}0.83+ \\
-0.00\end{array}$ & 10.00 & $\mathrm{Z}=0.92$ & $\mathrm{p}>0.0$ \\
\hline Total & $\begin{array}{l}902(1 \\
51)\end{array}$ & 3018 & $\begin{array}{l}3.35+ \\
-1.78 \\
\end{array}$ & 40.15 & $\begin{array}{l}1044 \\
(178)\end{array}$ & 4758 & $\begin{array}{l}4.55+ \\
-1.82 \\
\end{array}$ & 54.68 & $\mathrm{Z}=6$ & $\mathrm{P}=<0.0$ \\
\hline
\end{tabular}

It was seen than complete utilization of immunization service by the beneficiary children was $70.3 \%$. Immunization coverage in urban and rural area was nearly similar to the coverage reported by Punith $\mathrm{K}$ et al i.e. $(71.11 \%) .^{10}$ The overall prevalence of malnutrition in study area was $48.50 \%$ which was similar to prevalence reported by Shubhada S. Avachat et al ${ }^{11}$ (50.46\%). This percentage was less than the percentage of malnourished children reported by Bhatia $\mathrm{V}$ et $\mathrm{al}^{12}(65.87 \%)$, S. P. Mitra $^{13}(61.11 \%)$, Anita Khokhar $^{14}$ (60.7\%), K.D.Bhalani ${ }^{15}(62.9 \%)$. It was observed that majority of malnourished children were from grade I malnutrition. In urban area $22.65 \%$ and in rural area $30.64 \%$ children were suffering from grade I malnutrition which was nearly similar to reported by S. P. Mitra in $2007^{13}$ $(37.6 \%)$, Umesh Kapil et al ${ }^{16}(35.2 \%)$. The percentage of grade I malnourished children in study area was more than reported by A. Mittal et $\mathrm{al}^{17}$ (26.76\%), Arshad Farooq et $\mathrm{al}^{18}(24.14 \%)$. Though the percentage was more for grade I malnutrition there was decrease in grade II malnutrition.

Frequency of illness is high in India. A greater proportion of illness is due to preventable diseases borne by food,wsater, and facies and also due to bad environmental sanitation. In this study, $83.42 \%$ of urban ICDS children suffered from at least one spell of sickness during the 6 month of follow up, while in rural ICDS area the percentage of children was $95.69 \%$ the difference was statically significant (Table-3).

In present study most common morbidity in both the area was respiratory (Urban ICDS area-57.51\%, rural$71.51 \%)$. It was followed by gastro intestinal diseases (41.98\%) Pyrexia (24.31\%) skin diseases (14.19\%) and eye diseases $14.36 \%$ on the other hand in rural ICDS area gastro intestinal diseases (70.43\%) skin diseases $(37.09 \%)$ and eye diseases $33.33 \%$ Pyrexia(27.42\%). This compression shows the rural ICDS centres still to upgrade (Table-3).

A study was conducted in the urban slums of ICDS block, Vijiaiwada, Krishna District, Andhra Pradesh. Among children of 0-5 Years of age group it was observed that $20.8 \%$ did not suffer from any illness, $14.6 \%$ suffered from one episode of illness, $17 \%$ from 
two, 19.8 percent from three and $27 \%$ from more than three episodes of same or different illness. The same study also revealed that major cause of morbidity among the infants were diarrhea $(28.8 \%)$, Respiratory infection (19.4\%), Pyrexia(20.0\%), and minor infection and injuries $(24.7 \%$ ) and these were contributing to $92.9 \%$ of illness. The average spell of sickness was $2.2 \%{ }^{19}$

In this study average duration of sickness /child /year in urban ICDS area was 40.15 while in rural ICDS it was 54.68 means 24 days of illness in a year in urban area and 27.34 days of illness in rural ICDS area children that is burden of morbidity in rural area is very high (Table-4).

This is lower than the study coated by this book, children in India on an average suffer about 10.2 illness episodes which keep them sick for 51 days in a year and burden of morbidity in rural area is very high. This difference may be due to the sickness rate gradually decreasing after one to two year of age and sharp fall after the five years. The most common illness which retarded the normal growth of Indian infants is infection of gastrointestinal tract, Respiratory tract, skin Infection and other infectious diseases. ${ }^{19}$

This information shows that even the immunization status of children are improving in these area but the malnutrition and duration of sickness is still an eye opening problem in both urban and rural ICDS centers. It has to want change in field of complete immunization, eliminating mal nutrition and health care deliveries through ICDS.

\section{CONCLUSION}

As health and nutrition education emerged as the most significant component of the ICDS scheme, it needs to be consolidated and strengthen by further training of Anganwadi worker. Health care and referral services were observed to have poor response from the people. Also take action simultaneously, to improve the prevailing insanitary and unhygienic living conditions and eradicate the monstrous problem of poverty from our country.

\section{Recommendations}

- ICDS cell needs to be strengthened in terms of resources and training as the resource and training devoted is not sufficient to meet the requirement especially in rural area.

- II. Set up a Research Cell to conduct studies on child development and level of malnourishment in rural Anganwadi areas and urban-Anganwadi areas.

- Involvement of community in the provision of Health.

Funding: No funding sources

Conflict of interest: None declared
Ethical approval: The study was approved by the Institutional Ethics Committee

\section{REFERENCES}

1. Bashir A, Bashir U, Ganie Z, Ahmad. Evaluation Study of Integrated Child Development Scheme (ICDS) In District Bandipora of Jammu and Kashmir. Int. Res. J. Social Sci. 2014;3(2):34-6.

2. Park K. Text Book of Preventive and Social Medicine; 23rd.M/s Banarsidas Bhanot Publishers 1167, Prem Nagar, Jabalpur, 482001(M.P.) India 2011:101.

3. Alim F, Jahan F. Assessment of Nutritional Status of Rural Anganwadi Children of Aligarh .The ICDS and Rural Health Stud Home Com Sci. 2012;6(2):95-8.

4. Singh D, Gaur KL, Sharma MP. Performance evaluation of Anganwadi Workers of Jaipur Jone, Rajasthan. International Journal of Engineering Science Invention. 2013;2(4):28-34 .

5. Patil SB, Doibale MK. Study of profile, knowledge and problems of Anganwadi workers in ICDS blocks: A cross sectional study. Online J Health Allied Sci. 2013;12:1. Available from: http://www.ojhas.org/issue46/2013-2-1.html. (Accessed on 2015.12 March).

6. Evaluation Report Integrated Child Development Services (ICDS) Scheme-Guidelines for Monitoring and Supervision of the Scheme. Central Monitoring Unit (ICDS), National Institute of Public Cooperation and Child Development, New Delhi. Programme Evaluation Organisation Planning Commission .Government of India New Delhi110001 (available on planningcommission.nic.in/reports/peoreport/peoeva lu/peo_icds_v1.pdf (Accessed on 12/3/2015).

7. Indian National Science Academy. Nutrition security for India. 2009.

Available from www.medscape.com (Accessed on 2015.12 March).

8. Mumbai: India Reports International Institute for Population Sciences (IIPS); 2006. National Family Health Survey 2005-2006 (NFHS-3) (sited on 12/3/2015) India, Maharashtra: Mumbai IIPS; 2010. District Level Household and Facility Survey (DLHS-3). 2007-08: International Institute for Population Sciences (IIPS) )( sited on 12/3/2015

9. Punith K, Lalitha K, Suman G, Pradeep BS, Jayanth Kumar K. Evaluation of Primary Immunization Coverage of Infants Under Universal Immunization Programme in an Urban Area of Bangalore City Using Cluster Sampling and Lot Quality Assurance Sampling Techniques. Indian Journal of Community Medicine. 2008;33(3):151-5.

10. Shubhada S. Avachat, Vaishali D. Phalke, Deepak B. Phalke. Epidemiological study of malnutrition (under nutrition) among under five children in a section of rural area. Pravara Med Rev. 2009;4(2):20-2. 
11. Bhatia V, Puri S, Swami H M, Gupta M, Singh G. Malnutrition among Under-Six Children in Chandigarh: Scarcity in Plenty. Journal of Clinical and Diagnostic Research. 2007;1(6):483-7.

12. Mitra SP. A Study of Dietary Intake and Nutritional Status of Under Five Children in Slums of Kolkata City. Indian Journal of Community Medicine. 2007;1(1):92.

13. Khokhar A, Singh S, Talwar R, Rasania SK, Badhan SR, Mehra M. A study of malnutrition among children aged 6 months to 2 years from a resettlement colony of Delhi. Indian J Med Sci. 2003;57:286.

http://www.indianjmedsci.org/text.asp?2003/57/7/2 86/11948.

14. Bhalani KD, Kotecha PV. Nutritional status and gender differences in the children of less than 5 years of age attending ICDS anganwadis in Vadodara city. Indian Journal of Community Medicine. 2002;27(3):124-9.

15. Umesh Kapil, Tandon M, Pathak P, Nayar D. Nutrient Intake and Consumption of Supplementary
Nutrition by Severely Malnourished Children in two ICDS Projects in Rajasthan State. Indian pediatrics. 1999;36(8):799-802.

16. Mittal A, Singh J, Ahluwalia SK. Effect of Maternal Factors on Nutritional Status of 1-5-Year-Old Children in Urban Slum Population. Indian Journal of Community Medicine. 2007;32(4):264-7.

17. Farooq A, Calcutti R, Bakshi S. Nutritional Status of Under Fives on National Immunization Day in Srinagar. JK Science. 2002;4(4):177-180.

18. Department of population studies. Sri Venkateshwara University Tirupati (Andhra Pradesh)- India Infant Health: A Socio-demographic Analysis, 2008. Available at https://books.google.co.in/books?isbn=8183563295. Accessed 14 December 2015.

Cite this article as: Singh N, Gupta P. Impact of ICDS services in urban and rural area beneficiaries children of Ghaziabad, Uttar Pradesh, India: a comparative evaluation study. Int J Community Med Public Health 2016;3:287-92. 